\title{
CONCEPTUAL CATEGORY PERSON AND MEANS OF ITS VERBAL PRESENTATION IN THE FANTASY GENRE
}

\author{
Iryna Aleksandruk \\ Taras Shevchenko National University of Kyiv, Kyiv, Ukraine \\ ira9aleksandruk@gmail.com \\ Oksana Babelyuk \\ Lviv State University of Life Safety, Lviv, Ukraine \\ babelyuko@gmail.com
}

\begin{abstract}
The studies devoted to the issues of conceptualisation and categorisation of reality prove that language plays a key role in these two interrelated and interdependent processes. The purpose of the article is to analyse the structure of the conceptual category PERSON and the means of its verbal presentation in the fantasy genre. The data is collected from 85 fantasy novels written by British and American writers within the period from 1997 to 2012. The data includes 5890 nominative units (innovations, phrases, word combinations, sentences) either to name or characterise people of possible worlds presented in fantasy novels. The methods applied in this research are chosen considering the aim, objectives, and data. The contextual analysis, the analysis of definitions provided in the lexicographical sources and fantasy texts, and the morphemic analysis are used to analyse the data collected. According to the results of the research, the conceptual category PERSON has a complex hierarchical structure. Two sub-categories - the Name of a Person and the Group of People - are determined in the structure of this conceptual category. The sub-category Name of a Person comprises about 63\% (3730) of nominative units. Innovations are created by the writers to name or describe people of possible worlds, which comprise 79\% (4653) of all the data collected. Peculiar features of fantasy discourse, in general, may be the focus of further research. It is also planned to contribute to online dictionaries devoted to fantasy novels.
\end{abstract}

Keywords: conceptual category; categorisation; conceptualisation; possible world; nominative unit innovation.

\section{Introduction}

In modern linguistics, the processes of conceptualisation and categorisation of the world and the role of language in these processes have been the focus of research for many decades. These processes simultaneously occur in the consciousness of each human and are the examples of the human's ability to classify different phenomena that exist in the real world or are presented in the possible worlds described in the fantasy novels (Cohen \& Lefebvre, 2017; Esmaeili, Akhavan, \& Amjad, 2015; Nguyen, 2017). It should be noted that there is a slight difference between the processes of conceptualisation and categorisation. The former is aimed at establishing the minimal meaningful units of the mental level, which are the result of human's practical experience that leads to the formation of concepts, conceptual structures, and the whole conceptual system in the consciousness of a human (Cruse, 2006; Croft \& Cruse, 2004; Zhanalina \& Ordahanova, 2015). The latter is aimed at ordering different phenomena into various groups in accordance with specific kinds or types of similarity (Rosh, 2002; Dummett, 2006; Nguyen, 2017).

Even though categorisation is considered a conscious act that determines what group or category a specific item or phenomenon belongs to, it is also an essential cognitive process that provides cognitive building blocks or concepts, which guide people's interaction with reality, no matter whether real or possible (White, Storms, Malt, \& Verheyen, 2018). The categorical classification is the basis of the human's mental lexicon. The process of categorisation is based on determining specific features with the help of language means. Consequently, language categories are regarded as specific means of nomination (Anderson, 2007; White et al., 2018). It is proven that categories can change from language to language, from culture to culture and can belong to one or to several categories depending on different circumstances (Lakoff \& Johnsen, 2003; Talmy, 2007; Sharifan, 2017; Sohrabi, \& Pirnajmuddin, 2017). Lakoff and Johnsen (2003, p. 15) state that if the notion of the essence of a category is changed, the notion of the world will also change. Thus, in order to change the essence of a category, metonymy or metaphor is used (Lipka, 2006; Kövecses, 2010; Tawwab Sharaf Eldin, 2015).

Conceptual categories are referred to as cognitive instruments that perform certain functions, such as the function of cognition when the conceptual category is utilised a basis for comparing new and previous experience (Cruse, 2006; Kövecses, 2015; Sharifan, 2017); the function of cognitive economy (Győri, 2013), which allows identifying either the members of a specific category by a certain set of categorical features or the categories by one member only; and the communicative function, which enables the exchange of information from the writer to the reader (Croft \& Cruse, 2004). 
The conceptual category PERSON comprises a certain unity of members located at a certain distance from its centre. The structural peculiarity of the conceptual category is that it can include other categories and sub-categories. Each conceptual category is represented by a specific concept, which is its central element. The concept can be verbalised by means of different nominative units that disclose its meaning. Therefore, it is imperative to analyse the meaning of nominative units that verbalised a certain concept, as well as various cases of its presentation in discourse. It should be noted that the identification of the concepts is based on the denotative component of meaning and thus specific items of possible worlds that were created and verbalised by means of nominative units of different structure and semantics will be analysed in this article.

The aim of this paper is to determine and analyse the means of verbalisation and structure of the conceptual category PERSON. In accordance with the set aim, the objectives are as follows: to choose the means that verbalise the concept PERSON; to determine the structure of the conceptual category PERSON; to analyse structural, semantic, etymological and cognitive characteristics of nominative units that are used or created by American and British writers to name and describe people of possible worlds presented in their fantasy novels. The object of the research is nominative units (innovations, phrases, word combinations, sentences) used or created by American and British fantasy writers to name and describe people of possible worlds. The subject of this work is semantic, etymological, structural and cognitive characteristics of nominative units utilised by fantasy authors to describe people of possible worlds.

\section{Data and Methodology}

The paper is based on the data collected from 85 fantasy novels completed by American and British writers within the period from 1997 to 2012. The data of the research comprises 5890 nominative units (innovations, phrases, word combinations, sentences) that are utilised by American and British writers to name and describe people of possible worlds presented in their fantasy novels. The following research is based on the fact that language plays a key role in the cognitive and communicative activity of people that is realised in discourse. The choice of methods applied in this research is based on the aim, objectives and the collected data. The contextual analysis allows determining deep senses encoded in the nominative units used in the fantasy novels to name and describe people of possible worlds. The analysis of definitions given in the fantasy texts and lexicographical sources allows establishing language means that verbalise the concepts of the basic conceptual categories, such as PERSON. The conceptual analysis allows determining cognitive mechanisms that influence the creation and functioning of nominative units. The morphemic analysis allows establishing the morphemic structure of the innovations.

\section{Results and Discussion}

The conceptual category PERSON is one of the essential categories that represent the centre which both real and possible worlds are based on. The following conceptual category is represented by the concept PERSON. In the structure of the conceptual category PERSON, we determine two sub-categories: the Name of a Person and the Group of People. The sub-category, the Name of a Person, comprises the following components as the proper names of people, person by place of birth, characteristic by birth, and professional activity of a person.

All proper names of possible worlds' people used in fantasy novels can be subdivided into several groups. The proper names (first and last names) functioning in the lexical system of English or any other language of the world are referred to the first group, for instance, Bell Katie (Rowling, 1997); Corner Michael (Rowling, 2003); Wronski Josef (Rowling, 2003); Boot Terry (Rowling, 2003); Travers (Rowling, 2003); Edgar (Rowling, 2003); (Rowling, 1997); Fred (Rowling, 1997); Williamson (Rowling, 2003); Bertha (Rowling, 1997); Purkiss Doris (Rowling, 2003); Pucey Adrian (Rowling, 2003); Miranda (Rowling, 2003); Igor (Rowling, 2003); Anthony (Rowling, 2003); William (Rowling, 1997); Sloper Jack (Rowling, 2003); Jones (Rowling, 2003); Molly (Rowling, 1997); Charlie (Rowling, 1997). In this group, it is possible to identify the names and last names of people that derive from the proper names of real people. For example, Ptolemy and Agrippa are well-known wizards printed on the cards of chocolates popular in the

12356.wizard's world: Chocolate Frogs have cards, inside them, you know, to collect-famous witches and wizards. I've got about five hundred, but I haven't got Agrippa or Ptolemy (Rowling, 1997). It should be noted that the proper name of wizard Ptolemy comes from the name of Claudius Ptolemy, a famous GrecoRoman astronomer and mathematician. One of his works The Almagest is recognised as a very detailed source of ancient knowledge in the field of Astronomy and Mathematics (Tyle, 2002, p. 1528). Agrippa is the first name of Heinrich Cornelius Agrippa von Nettesheim, who was one of the prominent researchers working in different fields of science in the XV-XVI century. He is the author of De Occulta Philosophia 
Libri III (Three Books of Occult Philosophy) (Tyle, 2002). It is evident that the process of the category shift occurs when the proper names of real people are used as the proper names of people of the possible worlds.

Many proper names come from the proper names of cities, villages and towns. In the possible world created by Rowling, Bagshot Bathilda is the author of many works on the history of the wizard's society: She was a famous magical historian and author of one of Hogwarts' standard textbooks, A History of Magic and Hogwarts History of Magic (Rowling, 2007, 22). The last name of the character - Bagshot - derives from the name of the village situated in the south-eastern part of England (Ekwall, 1936, p. 22). The surname Whitby Kevin (Rowling, 2000) originates from the proper name of the English city located on the borderline between the county of Yorkshire and the territory of moors (Ekwall, 1936, p. 489).

Some proper names of people utilised by the fantasy writers originate from the proper names of different buildings located in various parts of the world. For instance, the proper name of wizard Zograf (Rowling, 2000) comes from the proper name of the Orthodox monastery situated in Mount Athos, Greece (Candy \& Lemberg, 2007). Urquhart (Rowling, 2005) is the last name of the student from the school of witchcraft. This last name derives from the proper name of the old castle situated not far from picturesque Loch Ness Lake (Candy \& Lemberg, 2007).

Other proper names of the possible world's representatives derive from the names of plants / herbs or their parts. The surname of the nurse at the school of magic - Madam Pomfrey (Rowling, 1999) - comes from the name of the herb "pomfrey", which was used by the medieval doctors to treat different blood diseases (Longmanonline.com, n. d.; Online Etymology Dictionary, n. d.). Wills Heliotrope (Rowling, 2003) is a witch who fights for the rights of other races inhabiting the world of wizards. The name of the heroin originates from the name of the garden plant with a nice smell and pale purple flowers (Online Etymology Dictionary, n. d.). Professor Spore specialises in herbs and fungi, as well as their magic properties. The proper name Spore comes from the name of seed produced by some plants and mushrooms (Wright, 1905, p. 682).

While analysing the collected proper names, we come across some names and surnames that derive from the words functioning in the English language. For example, the last name of the driver of the magic bus is Prang: Ernie Prang, an elderly wizard wearing very thick glasses; driver of the Knight Bus (Rowling, 2000). In English, prang means "to damage the vehicle in an accident" (Longmanonline.com, n. d.). It is evident from the context that the choice of this surname is based on the one of the characteristics of the driver who always gets into different problematic situations on the roads because of his speedy and careless driving. Madam Pince (Rowling, 2003) is a very irritable woman who spends most of her time policing the library instead of helping the students with their search of the needed books or other materials. The peculiar feature of this librarian is her habit of wearing huge, old-fashioned glasses. The last name of this character is formed by means of clipping of the word "pince-nez", meaning "glasses worn in the past that were held in position on the nose by a spring, instead of by pieces fitting round the ears" (Online Etymology Dictionary, n. d.).

Wizard Widdershins Willy is known for his evil deeds and actions that contradict the established norms and code of ethics followed in the wizard society: A ne'er-do-well fellow who set up a series of regurgitating toilets to confound the Muggles (Rowling, 2000). The surname Widdershins means "in a direction contrary to the sun's course, in the opposite direction" (Wright VI, p. 524). According to Wright (1905, p. 524), widdershins derives from Middle High German - widersinnes, in which wider "against" + sin "direction." In accordance with another version, the second element of the word was also associated with the Scottish word sin "sun". Wimple Gilbert is one of the ministers at the Ministry of Magic and the member of the Committee on Experimental Charms. The word wimple means "to wrap to cover, to folder" (Wright, 1905, p. 500). Flume Ambrosius is the owner of the Honeydukes Sweetshop in Hogsmeade (Rowling, 2000). The last name of the wizard comes from the word flume "an artificial channel conveying water used for transporting timber or logs" (Online Etymology Dictionary, n. d.).

Some proper names contain specific elements or words borrowed from other languages. The name Ambrosius originates from Greek ambrosia "food of gods (immortals)." Since 1731, this word has been used figuratively for anything delightful (Online Etymology Dictionary, n. d.). The representatives of one of the ancient wizard families have the last name Malfoy - Malfoy Abraxas (Rowling, 2005); Malfoy Draco (Rowling, 1997); Malfoy Scorpius (Rowling, 2007, p. 605); Malfoy Lucius (Rowling, 1999). This surname comprises Latin word-forming element mal "bad, ill, evil, wrong" (Online Etymology Dictionary, n. d.).) and English word foy "entertainment given to or by one about to make a journey" (Wright, 1905, p. 480). It should be noted that all members of this family were either imprisoned or sentenced to death for their evil actions against the representatives of both the real and wizard worlds. Thus, the program of heroes' actions is coded in the inner form of their last name. It is worthwhile mentioning that many members of the Malfoy's have very specific names that disclose their personality and traits of character. According to ancient 
Cabbalistic beliefs, Abraxas is a demonic creature with a head of a rooster, a body of a man, and legs of a scorpion (Coleman, 2007, p.14). The name Draco originates from the very tyrant ruler of Athens (the VII BC) known for his harshness (Online Etymology Dictionary, n. d.). Draco is also one of the largest constellations in the sky. The name Lucius derives from Latin lux (genitive lucis) "light" (Online Etymology Dictionary, n. d.). Scorpius derives from Latin scorpio (poetic scorpius), which is one of the zodiac constellations discovered in the southern hemisphere opened by Ptolemy in the II century.

The name Ama used by Pullman in his fantasy novel Amber Spyglass: Mrs. Coulter knew who she was: Ama had been bringing her food for some days now. Mrs. Coulter had let it be known when she first arrived that she was a holy woman engaged in meditation and prayer, and under a vow never to speak to a man. Ama was the only person whose visits she accepted (Pullman, 2000). This word comes from the Japanese language where it refers to the profession of women who dive into the sea in order to look for pearls (Subject Dictionary Glossary Lexicon Thesaurus, n. d.). Thus, it is evident that each proper name represents a microtext of specific information on the hero / heroine and his / her unique characteristics, which are realised in the context of the given fantasy text.

There are also nicknames given to the representatives of the possible worlds. For instance, Duddy (Rowling, 1999); Ickle Dudleykins (Rowling, 1997); Dudders (Rowling, 1999); Big D (Rowling, 2003); Duddydums (Rowling, 2003); Dinky (Rowling, 2003); and neffy-poo (Rowling, 1999) are the nicknames of Harry Potter's cousin, Dudley. In such nicknames as Dudders, Dudleykins, Duddy, Dudders, Duddydums there is a morpheme dud, "ragged, shabby or dirty clothing" (Wright, 1905, p. 201). The nickname Dinky, meaning "tiny, very small," is used ironically as Dudley was very tall and enormously overweight, but his parents treat him a little kid. Ickle, which is one of the elements in the nickname Ickle Dudleykins, is a childish variant of a pronunciation of "little" (Online Etymology Dictionary, n. d.). The nickname neffy-poo derives from an English dialect work neffy "nephew" and poo "excrement" (Wright, 1905, p. 251). Thus, the mediocrity, untidiness, ignorance, as well as some features of Dudley's character and appearance are reflected in his nicknames.

The second group comprises the proper names of people created by the authors of fantasy novels, which makes it impossible to determine their origin, for instance, Khaamil (Valente, 2006); Nynaeve (EW); Ulissa (Valente, 2006); Oubliette (Valente, 2006); Aukai (Valente, 2006); Alcazar (Valente, 2006); Keltset (Brooks, 1977); Balinor (Brooks, 1977); Ruhl Buckhannah (SS); Burgalass (Goodkind, 1995); Andellmere (Goodkind, 1995); Kohinoor (Valente, 2006); Gryll (Zelazny, 1991); Sawall (Goodkind, 1995); Suhuy (Zelazny, 1991); Belissa Minobee (Zelazny, 1991); Rhanda (Zelazny, 1991); Grayswandir (Zelazny, 1991); Eldrene ay Ellan ay Carlan (Jordan, 1990); Guaire Amalasan (Jordan, 1990);); al'Lan Mandragoran (Jordan, 1990); Ordith Condatith de Dackidvich (Goodkind, 1995); Ewin Finngar (Jordan, 1990); Aes Sedai (Jordan, 1990);).

In some proper names there are certain elements that indicate:

- the exact time of the person's birth - Yoi-who-was-born-in-the-evening (Valente, 2007); Idyll-whosupposes-he-was-born-at-night (Valente, 2007); Yil-who-supposes-he-was-born-at-night (Valente, 2007);

- the season of his / her birth - Yazo-who-was-born-at-the-bottom-of-winter (Valente, 2007);

- the availability of other names of the person - Roshaun-and-all-the-rest-of-the-names (Goodkind, 1997);

- the ability to change the colour of certain parts of the body - Mr. Now-They're-Hazel-Now-They'reBlue (Goodkind, 1997);

- the weather conditions that were at the person's birth - Ostraya-who-was-born-in-the-rain (Valente, 2007).

The concept PEPSON is also verbalised by means of extended descriptions that include elements naming:

- the title of the representative of the possible world - I am Borel, Duke of Hendrake, Master of Arms of the Ways of Hendrake (Zelazny, 1991); Sholto, Lord of That Which Passes Between, Lord of Shadows, King of the Sluagh (COT); Merlin, Prince of the House of Sawall, Prince of Chaos came up (Zelazny, 1991); Lord Rahl, the Seeker of Truth and wielder of the Sword of Truth, the bringer of death, the Master of D'Hara, the ruler of the Midlands, the commander of the gar nation, the champion of free people and bane of the wicked and the betrothed of the Mother Confessor, the guardian of a secret, the true owner of the book (Goodkind, 1994); Martland Redbeard, the Earl of Thun (Paolini, 2008); His Royal Highness, King of the Eight Kingdoms and Steward of the Eastlands, Autokrator of the Unified Tribes, Lord of the Thousand Caves, the Sacred Vessel who owns all above and below earth (Valente, 2006);

- the title by birth - It was Tmer, of the House of Jesby, the eldest son of the late Prince Rolovians (POC); Lord Bances of Amblerash, a distant relative and long-time friend of our late monarch (Zelazny, 1991); 
- the profession or craft - Dras-Leona's governor, Marcus Tabor (Paolini, 2008); Allanon - the mysterious wanderer of the four lands, the historian of the races, the philosopher and teacher, and, some said, practitioner of the mystic arts, Allanon, the man who had been everywhere from the darkest havens of the Anar to the forbidden heights of the Charnal Mountains (Goodkind, 1994).

- race or kin relationship - Glumra, a dwarf woman of the Family of Mord, she who was the mother of Kvistor (Paolini, 2008);

- unique features of the appearance - Yarbog's large black fingernails, his fangs, his horns, and his leathery hide (Paolini, 2008).

The component Person by place of birth comprises lexical units that name a person or a group of people living in a certain place or at a specific territory - the Sea Folk (Jordan, 1990); the steppe-women (Valente, 2006); tree people (Valente, 2006); tree-girl (Valente, 2006); hedge-witch (Brooks, 1992, p. 182); the Vale people (Jordan, 1990); house-elves (Rowling, 2000); the Sky Elves (Brooks, 1992, p. 46); the Land Elves (Brooks, 1992, p. 66). In the tribe's name the Mud People, the word mud describes a geological feature of the territory they live, as well as their habit of using it as a kind of camouflage: Sticky mud that didn't wash away in the rain was smeared over the rest of their skin and faces, and their hair smoothed down with it. Kahlan recognized several of the men; it was a hunting party of Mud People (Goodkind, 1994).

In the name the Westlander the geographical location of the territory in reference to the parts of the possible world is explicated: They were brothers, the elder called Durin, a slim, quiet Westlander who gave the instant impression to Shea and the ever-present Flick that he was a man to be trusted (Jordan, 1990).

In the possible world created by Pratchett, there is a territory called the Hub, which is situated in permafrost and none of the sun rays can get there. The tribe of wizards living at that territory are referred to as the hublanders: "You are being brought to Krull," said the girl. And don't mock me, hublander. Else I'll use the wand (Pratchett, 1983). Those people living at the borderland of two worlds are known as either the Bordermen or the Shienar in their language: We of Shienar call ourselves Bordermen, but fewer than fifty years ago, Shienar was not truly of the Borderlands. North of us, and of Arafel, was Malkier (Jordan, 1990).

The concept PERSON is verbalised by means of the nominative units that belong to the component Characteristic by birth. The innovations such as half-man (Jordan, 1990), quarter-man (Jordan, 1990), and part-humans (Rowling, 2003) are created by fantasy authors to name the races of the possible worlds. The words part / half / quarter are used to indicate the fact that one of the parents does not belong to the world of wizards. In the innovations half-elf (SS); half-giant (Rowling, 2000); half-pixie (Hamilton, 2002); part-sidhe (Hamilton, 2002); part-were (Hamilton, 2002); part-Veela (Rowling, 2000); quarter-Djinn (Valente, 2007), it is evident that a parent belongs to one of the magic races inhabiting possible worlds. It should be noted that in the cases mentioned above, fantasy writers simply refer to the folklore traditions of different countries in order to create their own unique characters of their possible worlds.

According to ancient legends believed in Somersetshire, pixies usually harm horses. In Cornwall, it is believed that pixies are very small, funny and harmless creatures that are usually dressed in green. On the contrary, in Devonshire, pixies are believed to be good spirits that appear in the form of small children in order to help with different household chores (Wright, p. 530). In Irish and Scottish mythology, the sidhe or shee / sid / sith is a representative of "fairy folk living in the enchanted mounds" (Coleman, 2007, p. 936).

In southern Europe, the vela is referred to a woodland sprite, which is fond of dancing and can get married to a mortal (Coleman, 2007, p.1074).

In Moroccan folklore, the Djinn or Jinnee is a demon that can take control of humans. In ascending order of their power, there are five orders of these demons jann, jinn, shaitan, efrit, and marid. They can easily transform in any animal and get married to humans (Coleman, 2007, p.554).

The innovation Muggle-born (Rowling, 1998) is used to name a representative of the possible world who has an inborn magical gift, but the peculiar feature of such a man is that his / her parents are ordinary humans without magic powers. In the IX century, a word muggle means "mess, confusion, or disorder" (Wright, 1905, p. 195). Another meaning of muggle is "marihuana," which was first indicated in the American dictionaries in 1926 (Online Etymology Dictionary, n. d.). The innovation half-and-half (Rowling, 1997) refers to a wizard one of the parents is a witch / wizard and another one is an ordinary human. NonWizard (Rowling, 2000) denotes a human who does not belong to the world of wizards.

Some innovations are used to name the exact belonging to specific ethnic groups of possible worlds goblin-sidhe: Kitto was a goblin-sidhe hybrid, given to Merry by Kurag as part of their alliance (Hamilton, 2002). The human who can easily transform into different animals is referred to as a shapechanger: I nod, proud the boy could ignore the pain and the attack long enough to focus on what he must do to save himself. Like me, like his mother, like all of our kind, the boy is a shapechanger, a far more dangerous foe than the animal realizes (Troop, 2003). The shape-shifter (Rowling, 1999) is a representative of the possible world 
who is capable not only of transforming in whatever animal he /she wants but also of getting into other parallel dimensions. In some possible worlds, each human has a close magical tie with a certain animal, which is a source of knowledge, inspirations, and protection. Some of such humans can even transform into their totemic animals, thus getting their specific names as wolf-girl (Valente, 2006); fox-girl (Valente, 2006); werleopard (Harris, 2009). In the innovation werleopard (Harris, 2009), there is Old English wer "man, male person" (Online Etymology Dictionary, n. d.). The representatives of the seal people are animals since their birth, but with time, they can leave their skin at night and become humans for a while: The skin was a magical device for shape-shifting (Harris, 2009).

The innovation UnWitted is used to name the representative of the possible worlds who have no inborn magical gift: that she (Laurel) was Witted, that she was unWitted child in the family. Those who are witted should have to choose, early in their lives, which they will bind to, an animal or another human (Hobb, 2002, 408).

The innovation Metamorphmagus names the representative of the wizard work who has an inborn ability to easily change his / her appearance (the colour of hair, height and weight, the size of some parts of the body, etc.): 'I'm a Metamorphmagus,' she said, looking back at her reflection and turning her head so that she could see her hair from all directions. 'It means I can change my appearance at will,' she added, spotting Harry's puzzled expression in the mirror behind her. 'I was born one (Rowling, 2003). This innovation includes Latin prefix meta "change," (Souter et al., 1968, p. 1105) and Greek morph "form, look" and magus "human" (Online Etymology Dictionary, n. d.; English-Geek Dictionary, n. d.).

The component Professional activity of a person includes innovations that name professions, occupations, or crafts of people of possible worlds. The word wizard is used in many innovations created by the authors of fantasy novels to name professions connected with magic, such as saleswizard (Rowling, 1997); the Chairwizard of the International Association of Quidditch (Rowling, 1997); Dark-wizard-catcher (Rowling, 2000); wizard-warriort (Paolini, 2008); spokeswizard (Rowling, 2003); the Wizard Healer-inCharge (Rowling, 2003); the Head of the Department of Magical Law Enforcement (Rowling, 2003); nightflyer wizard (Hamilton, 2000); the court Wizard (Valente, 2007). A war-wizard (Goodkind, 1994) is an occupation of the wizard who specialises in starting and leading wars with other races of the possible world. A Dark wizard catcher (Rowling, 2003) is the profession of the wizard specialising in catching dark and evil wizards is.

A specific place or an object related to a profession or a craft is used in the names of such professions as the Keeper of Keys and Grounds (Rowling, 2003), the Arch-astronomer of Krull (Pratchett, 1983)the Keeper of the Portkey (Rowling, 2003), a tree-guardian (Rowling, 2003); a wand-maker (Rowling, 2000); a bladesmith (Paolini, 2008); an Arch-astronomer (Pratchett, 1983); a broomstick designer (Rowling, 2007, 212).

In the world of wizards, there are also ruling organs with their workers, such as the Minister of Magic: The stranger had rumpled grey hair and an anxious expression, and was wearing a strange mixture of clothes: a pinstriped suit, a scarlet tie, a long black cloak, and pointed purple boots. Under his arm he carried a lime-green bowler. That's Dad's boss! Ron breathed. Cornelius Fudge, the Minister of Magic! (Rowling, 1998). In one of the possible worlds, a dark wizard chooses a boy who must describe each particular day of the wizard's life in detail. Consequently, the professional is called a day: the man, simply called by his vocation, Days, was a chronicler of sorts - a devotee of the Time Lords (Farland, 1998). The innovations are utilised to name the crafts taken up by the representatives of the possible worlds. In the educational system of the wizards' world, there are such professions as the Headmaster of Hogwarts (Rowling, 2000); the Apparition Instructor (Rowling, 2005); Defence Against the Dark Arts teacher (Rowling, 1999); Hogwarts Professor for the Study of Ancient Runes (Rowling, 2000); the Headmistress of Hogwarts (Rowling, 2000); the Care of Magical Creatures teacher (Rowling, 1999). The name of the profession Mediwizard (Rowling, 2000) is formed by means of clipping medical + wizard. It is evident that the meaning of each innovation is realised in the context where it is used by the authors of the fantasy novels.

The sub-category Group of People comprises such components as nation / race / ethnic group, family, clan, tribe, and humankind. In the possible world there exist such nations, races and ethnic groups as Merepeople (Rowling, 2000); Red caps (Rowling, 2003); boggarts (Rowling, 2003) hinkypunks (Rowling, 2003); grindylows (Rowling, 2003); Kappas (Rowling, 2003); werewolves (Rowling, 2000); elfs (Paolini, 2008); dwarfs (Paolini, 2008); Rollai (Pullman, 2000); Aielman (Jordan, 1990); the Blue Ajah (Jordan, 1990); the Red Ajah (Jordan, 1990); Sluagh (Hamilton, 2002); the Tuatha'an (Jordan, 1990); Nangtong (Goodkind, 1997); the Rock Trolls (Jordan, 1990) the Manetheren (Jordan, 1990); the Stors (Hamilton, 2002); the Urimites (Valente, 2006); the Urgasl (Paolini, 2008); the Gnomes (Paolini, 2008); flame-weavers (Farland, 1998). In the name of the ethnic group the Blue Ajah (EW) and the Red Ajah (EW), the names of colours indicate the colour of flags and attire that distinguish the representatives of these ethnic groups from 
other nations. The Nangtong (Goodkind, 1997) is the name of the ethnic group: It is their belief that the newly departed spirit will carry the Nangtongs' respects and requests to their departed ancestors, and in return the spirits will look kindly upon them (Goodkind, 1997). The name of this group comes from the Chinese province located not far from the mouth of the Yangtze River (Oxford Reference Online, n. d.). The flame-weavers are the representatives of the ethnic group that can destroy everything on their way with the help of fire: Each of the flame-weavers would reach up to the sky and grasp the sunlight, so that for a moment the whole sky would darken, and then strands of twisted light and heat would plummet into their hands and sit glowing like small suns, just before the flame-weavers hurled (Farland, 1998).

The Red Cap is a representative of the ethnic group of possible worlds: You've covered boggarts, Red Caps, hinkypunks, grindylows, Kappas, and werewolves, is that right (Rowling, 2000). According to Scottish folklore, red-caps or red-cowls are cruel dwarfs that live in the ruined castles and kill alone travellers staying nearby their places. They use the blood of their victims to dye their caps. If the blood on the caps dries out, a red-cap will die (Wright, 1905, p. 68).

The boggart / bogard / boggie / boggle / bugart/ buggart / is considered to be a kind of hobgoblin that terrifies or plays ill-natured tricks on people (Wright, 1905, p. 326). The grindylow is also one of the representatives of the wizard's world: The grindylow bared its green teeth and then buried itself in a tangle of weeds in a corner.

In England and Scotland, the grindylow also referred to as Jenny Green Teeth, is believed to be a water sprite or a nymph that lives in small ponds or lakes and hunts children who come close to its spots. The peculiar features of these sprites are their long arms, enormously huge green teeth, and attire made of weeds (Wright, 1905, p. 730).

The kappa is also one of the races inhabiting the world of wizards: They moved on to kappas, creepy water-dwellers that looked like scaly monkeys, with webbed hands itching to strangle unwitting waders in their ponds (Rowling, 1999). In Japanese folklore, the kappa is a creature with a head of a monkey, a body of a turtle, and only some features of a face resemble those of a human's one. The kappa is believed to have both evil and good qualities depending on a situation. Its usual habitat includes ponds, lakes, and rivers. The kappa carries water in a hollow space placed on top of its head. If the water spills from that space, this creature can lose its magical powers. If a human throws a cucumber into this creature, he /she will be able to avoid death, as it likes eating this vegetable. If the kappa is made to promise something, it will always follow this promise (Parks, 2002, p. 604).

The representatives of the sluagh race (Hamilton, 2002) have the inborn ability to attend other possible worlds getting through the mirrors. According to the Irish and Scottish beliefs, the sluagh is a soul of the sinner that is in-between the paradise and the hell. They are believed to come from the west to those people who are supposed to die soon in order to take their souls. In Scotland, people always close all windows and put cloths on the mirrors in order to prevent any intrusions of these evil spirits (Coleman, 2007, p. 950).

Clan. The craft of the clan is presented in their name - the Knurlcarathn, the stoneworkers clan (Jordan, 1990). The innovation of the clan Vrenshrrgn, War Wolves, Wolves of War names the clan whose key priority is to lead wars, kill other people and siege other territories: Yes, knurlagn of the clan Vrenshrrgn, War Wolves, Wolves of War, however you might say it in this tongue. I fell in with them, became drunk on ale, and as they were hunting Nagran, decided that I too should kill a boar and bring it to Hrothgar to appease his anger at me (BR).

Family. One of the families of the possible world created by Paolini is called the Family of Mord: Go, and do not return until I send a messenger for you, even if the Family of Mord turns you away and you must sit on a stalagmite until morn. But, Eragon, be you careful; the deep dwellers keep to themselves for the most part, and they are prickly to an extreme about their honour, and they have strange customs of their own. Tread carefully, as if you were on rotten shale, eh? (Paolini, 2008). In the name of the family, there is German mord "death" (Online Etymology dictionary, n. d.) that explicates an evil and unpredictable nature of its members.

\section{Conclusions}

The conceptual category PERSON is one of the categories that form the basis of the conceptual system not only of reality but also of possible worlds. Therefore, the human consciousness refers to basic categories in order to understand possible reality. According to the results, the conceptual category PERSON has a very complicated hierarchical structure. Thus, it is evident that American and British authors use different nominative units in order to name and describe people of possible worlds presented in their fantasy novels. Two sub-categories - the Name of a Person and the Group of People - were determined in the structure of the conceptual category PERSON. The concept PERSON is verbalised by various nominative units, 
including innovations, word combinations, and sentences. It should be noted that the sub-category Name of a Person includes about 63\% (3730) of nominative units. Innovations created or used by the writers to name or describe people of possible worlds comprise 79\% (4653) of all the data collected. Specific features of fantasy discourse in general or any fantasy writer, in particular, may be the focus of further research. It is also planned to contribute to different online dictionaries devoted to fantasy novels written by a certain American or British writer.

\section{References:}

Anderson, J. M. (2007). The grammar of names. Oxford, New York: Oxford University Press.

Brooks, T. (1977). The sword of Shannara. Retrieved March 07, 2017 from http://dloadvad.ru/new/book.php?id=115049923

Brooks, T. (1992). The elf queen of Shannara. London: Random House.

Candy, C \& Lemberg, D. S. (2007). Encyclopaedia of historic places (Rev. edn.). New York: Facts on File.

Cohen, H. \& Lefebvre, C. (Eds.). (2017). Handbook of categorisation in cognitive science (2-d edn.). New York: Elsevier Science.

Coleman, J. A. (2007). The dictionary of mythology: An A-Z of themes, legends and heroes. London: Arctaros.

Croft, W., \& Cruse, D. (2004). Cognitive linguistics. Cambridge: Cambridge University Press.

Cruse, A. D. (2006). A glossary of semantics and pragmatics. Edinburgh: Edinburgh University Press.

Dummett, M. (2006). Thought and reality. Oxford, New York: Oxford University Press.

Ekwall, E. (Ed.). (1936). The concise dictionary of English place names. Oxford: The Clarendon Press.

Esmaeili, P., Akhavan, B., \& Amjad, F. A. (2015). Metaphorically speaking: Embodied conceptualization and emotion language in Tim O'Brien's The Things They Carried. International Journal of Applied Linguistics and English Literature, 4(5), $137-$ 146. https://doi.org/10.7575/aiac.ijalel.v.4n.5p.137

Farland, D. (1998). Runelords: The sum of all men. Retrieved March 9, 2017 from http://bookgedebook.tk/downloads/all-the-men-ofthe-bible.pdf

Glucksberg, S. (2008). How metaphors creates categories. In R. W. Gibbs, Jr., (Ed.), The Cambridge handbook of metaphor and thought (pp. 67-84). Cambridge: Cambridge University Press.

Goodkind, T. (1994). Wizard's first rule. Retrieved March 02, 2017 from http://www.bitbenbrewer.weebly.com/uploads/2/3/5/4/23542696/goodkind_terry_-_sword_of_truth_01_-_wizards_first_rule.pdf

Goodkind, T. (1995). Stone of tears. Retrieved March 1, 2017 from http://www.nepad-ippf.org/Stone-Tears-2-Sword-Truth-Collection

Goodkind, T. (1997). Temple of the winds. Retrieved March 3, 2017 from http://friendsoflagunaseca.org/Blood-Sword-Truth-TerryGoodkind

Győri, G. (2013). Basic level categories and meaning in language. Argumentum, 9, 149-161. Retrieved April 23, 2018 from http://argumentum.unideb.hu/2013-anyagok/kulonszam/06_gyorig.pdf

Hamilton, L. K. (2002). Caress of twilight. Retrieved January 26, 2017 https://archive.org/details/caressoftwilight00laur

Harris, C. (2009). Dead and gone. Retrieved July 12, 2018 from http://bookgedebook.tk/downloads/dead-and-gone-a-sookiestackhouse-novel.pdf

Hobb, R. (2002). Fool's errand. London: Harper Collins Publishers.

Jordan, R. (1990). Eye of the world. Retrieved March 01, 2017 from http://stealthgerbil.com/files/pdf/The\%20Eye\%20of\%20the\%20 World\%20-\%20Robert\%20Jordan.pdf

Kövecses, Z. (2010). Metaphors: A practical introduction (5th edn.). Oxford, New York: Oxford University Press.

Kövecses, Z. (2015). Surprise as conceptual category. Review of Cognitive Linguistics, 13(2), 270-290. https://doi.org/10.1075/rcl.13.2.01kov

Lakoff, G. \& Johnsen, M. (2003). Metaphors we live by. London: The University of Chicago Press, 2003.

Lipka, L. (2008). Lexical creativity, textuality and problems of metalanguage. In J. Munat (Ed.), Lexical creativity, texts and contexts. Amsterdam: J. Benjamin Publishing Company, 58, 3-13.

Longmanonline.com. (n. d.). Retrieved February 23, 2018 from https://www.ldoceonline.com

Online Etymology Dictionary. (n. d.). Retrieved March 07, 2018 from http://www.etymonline.com

Nguyen, V. T. (2017). The cross-cultural analysis of the metaphorical conceptualization of happiness in English and Vietnamese. Review of Cognitive Linguistics, 14(2), 275-302. https://doi.org/10.1075/rcl.14.2.02ngu

Paolini, C. (2008). Brisingr. Retrieved February 02, 2017 http://ivoryfreevermont.org/Brisingr-Inheritance-Cycle-Book-3

Parks, R. (Ed.). (2009). UXL encyclopaedia of world mythology. London: Gale Learning.

Pratchett, T. (1983). Colour of magic. Retrieved February 12, 2017 from http://img0.liveinternet.ru/images/attach/c/2/3820/3820555_pratchett_terry_discworld_01_colour_of_magic.pdf

Pullman, P. (2000). Amber spyglass. Retrieved March 04, 2017 from https://hpl.bibliocommons.com/item/show/176554125_the_amber_spyglass

Rowling, J. K. (1997). Harry Potter and the sorcerer's stone. Retrieved June 02, 2017 from http://www2.sdfi.edu.cn/netclass/jiaoan/englit/download/Harry\%20Potter\%20and\%20the\%20Sorcerer\%27s\%20Stone.pdf

Rowling, J. K. (1998). Harry Potter and the chamber of secrets. Retrieved June 10, 2017 from https://www.lake.k12.fl.us/cms/lib/FL01000799/Centricity/Domain/4432/Harry\%20Potter\%20and\%20the\%20Chamber\%2 0of\%20Secrets.pdf

Rowling, J. K. (1999). Harry Potter and the prisoner of Azkaban. Retrieved January 12, 2017 from http://ebook.pldworld.com/_eBook/Harry\%20Potter\%20(1 7)/J.K.\%20Rowling\%20-\%20HP\%203\%20$\% 20$ Harry\%20Potter\%20and\%20the\%20Prisoner\%20of\%20Azkaban.pdf

Rowling, J. K. (2000). Harry Potter and the goblet of fire. Retrieved March 11, 2017 from http://ebook.pldworld.com/_eBook/Harry\%20Potter\%20(1 7)/J.K.\%20Rowling\%20-\%20HP\%204\%20$\% 20$ Harry\%20Potter\%20and\%20the\%20Goblet\%20of\%20Fire.pdf

Rowling, J. K. (2003). Harry Potter and the order of the phoenix. Retrieved January 21, 2017 from http://zf.carsondemand.ie/harry_potter_the_order_of_phoenix.pdf 
Rowling, J. K. (2005). Harry Potter and the half-blood prince. Retrieved January 24, 2017 from https://drive.google.com/file/d/1XGrneuYtc4hL06-5T321B2r0hBvELH74/view

Rowling, J. K. (2007). Harry Potter and the deathly hallows. London: Bloomsbury.

Rosh, E. (2002). Principles of categorisation. In D. J. Levitin (Ed.), Foundations of cognitive psychology: The study of cognition (pp. 251-269). New York: The MIT Press Publication.

Sharifian, F. (2017). Cultural linguistics and linguistic relativity. Language Sciences, 59, 83-92. https://doi.org/10.1016/j.langsci.2016.06.002

Sohrabi, Z. \& Pirnajmuddin, H. (2017). John Donne's metaphors of self and empire: A cognitive analysis. 3L: Language, Linguistics, Literature, 23(2), 14-26. http://dx.doi.org/10.17576/3L-2017-2302-02

Souter, A. et al. (Eds.). (1968). Oxford Latin-English dictionary. Oxford: The Clarendon Press.

Subject Dictionary Glossary Lexicon Thesaurus (n. d.). Retrieved March 12, 2018 from http://www.ats-group.net/glossarylexicon.html

Talmy, L. (2007). Foreword to methods in cognitive linguistics. In M. Gonzalez-Marquez, I. Mittelberg, and S. Coulson (Eds.), Methods in cognitive linguistics (pp. 11-22). New York: John Benjamin Publishing.

Tawwab Sharaf Eldin, A. A. T. (2015). A cognitive metaphorical analysis of selected verses in the glorious Qu'ran. International Journal of Applied Linguistics and English Literature, 4(2), 193-198. http://dx.doi.org/10.7575/aiac.ijalel.v.4n.2p.193

Troop, A. F. (2003). Dragon moon. Retrieved March 11, 2017 from http://www.greylib.su/?category=englishengfan\&altname=dragon_moon

Tyle, B. L. (Ed.). (2002). UXL encyclopaedia of world bibliography (Vols. 1-10). London: Gale Learning.

Valente, C. M. (2006). The orphan's tales: In the night garden. Retrieved January 15,2017 from https://napateltho1980.files.wordpress.com/2015/08/the-orphans-tales-in-the-night-garden-by-catherynne-valente.pdf

Valente, C. M. (2007). The orphan's tales: In the cities of coin and spice. Retrieved March 08,2017 from http://freeofread.com/download/in-the-cities-of-coin-and-spice-orphans-tales-2-catherynne-m-valente/

White, A., Storms, G, Malt, B. C. \& Verheyen, S. (2018). Mind the generation gap: Differences between young and old in everyday lexical categories. Journal of Memory and Language, 98, 12-25. http://dx.doi.org/10.1016/j.jml.2017.09.001

Wright, J. (Ed.). (1905). The English dialect dictionary (Vols. 1-6). Oxford, London, New York: Henry Frowde.

Zelazny, R. (1991). Prince of chaos. Retrieved March 13, 2017 https://royallib.com/read/Zelazny_Roger/Prince_of_chaos.html\#0

Zhanalina, L. K. \& Ordahanova, A. B. (2015). Substance and methods of cognitive approach in linguistics. Procedia: Social and Behavioral Sciences, 192, 720-723. https://doi.org/10.1016/j.sbspro.2015.06.071 